\title{
Privatisation of a socialist mall in Sarajevo
}

Mehdi Belasri*

\begin{tabular}{|c|c|}
\hline A R T I C L E IN F O & A B S T R A C T \\
\hline Received: July 9, 2021 & $\begin{array}{l}\text { This article focuses on the transformation of post-socialist } \\
\text { cities through the prism of consumption with the case of BBI }\end{array}$ \\
\hline $\begin{array}{l}\text { Received in revised } \\
\text { form: November } 1,2021\end{array}$ & $\begin{array}{l}\text { Centar, a shopping center located in Sarajevo, Bosnia and } \\
\text { Herzegovina. This paper attaches great importance to long- } \\
\text { term analysis and retraces the evolution of this place from the }\end{array}$ \\
\hline $\begin{array}{l}\text { Accepted: November } 7 \\
2021\end{array}$ & $\begin{array}{l}\text { construction of the first mall in } 1974 \text { to the construction of the } \\
\text { current one in } 2009 \text {. This manuscript's aim is to discuss the } \\
\text { notion of post-socialism through consumption, focusing on the }\end{array}$ \\
\hline Published online: & place of private actors in the socialist and post-socialist cities \\
\hline November 26, 2021 & $\begin{array}{l}\text { and on the relationship between private investors and public } \\
\text { authorities in a context of privatisation }\end{array}$ \\
\hline
\end{tabular}

Key words: consumption, privatisation, post-conflict, post-socialism, globalisation.

To cite this article: Belasri, M. (2021). Privatisation of a socialist mall in Sarajevo. Urbana, 22, 2139. Retrieved from http://www.urbanauapp.org/

https://doi.org/10.47785/urbana.5.2021

* Ph.D. EHESS and University Paris 8. m.belasri@live.fr 


\section{Introduction}

Sarajevo is the capital city of Bosnia and Herzegovina since the country declared its independence from Yugoslavia in April 1992. With a population of just over 400,000 inhabitants the city has undergone deep changes since the 1990s. Within a transition from a socialist planned economy, with a substantial decentralisation and elements of a market economy, to a liberal and market economy, the city also experienced a conflict lasting for almost four years, from April 1992 to February 1996, and suffered from one of the longest sieges in modern warfare.

The notion of post-socialism, at the core of this special issue and this very article, was originally coined in the early 1990s, in a moment of imprecision when socialist powers disappeared. The challenge of this approach was, above all, to conceptualise a phenomenon that concerned the whole world at a sudden moment (Müller, 2019). Although the term became global and referred to the new reality of a post-cold-war world (Geoffray, 2013), it fell out of use and became limited to regional studies about Central Eastern European countries (Geoffray, 2013). This explains some of the term's shortcomings: it restricts the conceptual framework to its geographical dimension and puts an emphasis on rupture over continuity. In other words, post-socialism is a notion that understands Eastern and Central European countries through a very temporary issue, the disappearance of socialism at the end of the 1980s. Indeed, the transition from socialism to what is yet to be defined is over and is one of many. The socialist experience of Bosnia and Herzegovina was relatively short-lived since it lasted roughly 45 years, from 1945 to 1990, after 400 years under Ottoman rule and more than 50 years of the Habsburgs' presence. Besides, post-socialism reifies socialism as a unique experience (Müller, 2019). In contrast, socialism in Yugoslavia, with its market-oriented mechanisms and decentralisation, was quite different from what Albanians or East Germans experienced during the same period. Therefore, this manuscript aims to work on continuities, with reference to former historical presence when necessary and point out specificities of the local context.

When the geographer Sonia Hirt argues that the post-socialist city witnesses a shrinking of public spaces, a transformation of its economic system from a predominance of industry to services, a reorientation of mobility towards individual modes, she highlights the post-public nature of socialist cities which are therefore managed by the private sector (Hirt, 2012). Thus, she suggests, along with several other scholars (Bădescu, 2014; Vasilevska et al., 2015; Em, Ward, 2021), to study the post-socialist city as an analytical tool that should be understood as a category for the study of spatial transformations and not as a description of these transformations. Every city could thus encounter the dynamics of the post-socialist city, where private actors are prevalent (Hirt, Tuvikene, Ferenčuhová, 2017). To summarise the question "is Sarajevo a post-socialist city?" should be rephrased into "how reasoning within the lens of post-socialism could provide a better understanding of Sarajevian realities?

The Dayton Agreement ${ }^{1}$ on 14 December 1995 officially put an end to the war in Sarajevo, however, the siege continued until the complete withdrawal of Serb-Bosnian forces in February 1996. The city, victim of a 3-year-long-siege, had to be largely rebuilt (Ristic, 2018). As evidenced by Gruia Bădescu in the cases of German cities after the Second World War, after a conflict, the objectives of the reconstruction of a city are to repair and to provide the necessary infrastructure for practical needs of the population such as housing, sewage systems, water, electricity (Bădescu, 2014). However, Sarajevo's case is somewhat different from other cities that suffered from similar destruction, such as Beirut in Lebanon or some cities in Israel and Palestine. Indeed, unlike these places where the end of the war was blurred and

\footnotetext{
${ }^{1}$ An agreement signed 14 December 1995 between the representatives of Bosniaks, Croatia and Yugoslavia ending the war in Bosnia and Herzegovina.
} 
the post-conflict period began while fighting was not over, in Bosnia and Herzegovina, the conflict stopped almost immediately after the Dayton Agreement of 1995 (Bougarel, 1996), although occasional flare-up of violence still occurred, especially in the neighbourhoods occupied by the Serb-Bosnian army during the siege and re-incorporated to the city of Sarajevo $^{2}$ during 1996 (Martín-Díaz, 2021). Reconstruction then rapidly started under the firm supervision of the international community (Goldstein, 2015; Gül, Dee, 2015; Pobric, Robinson, 2019; Martín-Díaz, 2021), and liberalisation of the economy resumed. The destruction of large parts of the city by bombings during the siege also accelerated the economic transition, freeing spaces for construction or capitalist valorisation. This land, mainly located along railway tracks and in the west part of the city (Husukić, Zejnilović, 2017), was reinvested by new companies active in new economic activities such as warehousing or shopping. New shopping centres and large-scale housing projects were built in former factories or closed public companies (Nurković, 2016). As a post-conflict situation implies the inscription of the consequences of a conflict on society and therefore in the urban landscape and post-socialism is a category for the study of spatial transformations such as privatisation of spaces and public assets, in the case of a post-conflict Sarajevo, analysis around post-socialism requires specific attention both to reconstruction and to privatisation. In this sense, this manuscript addresses the transformations of a post-socialist Sarajevo under the prism of consumption, understood as a cultural and spatial fact which ought to represent a way to understand changes, reconstruction and processes of privatisation in post-socialist cities.

In this study of post-socialist cities through consumption, I chose to focus on the case of a shopping centre in Sarajevo, BBI Centar, located in the very centre of the city, along the main pedestrian axis. This shopping centre includes a large public square and is in a situation of semi-continuity with the socialist period as it is located on the same site as a Sarajka, a department store built in 1974, bombed during the siege of the city and destroyed in 2006. The study of this place will allow me to attach great importance to long-term analysis and retrace the evolution of this place from the construction of the first mall in the 1970s to the construction of the current one in the late 2000s and to highlight a territorial organisation and its evolution through the use of this commercial space.

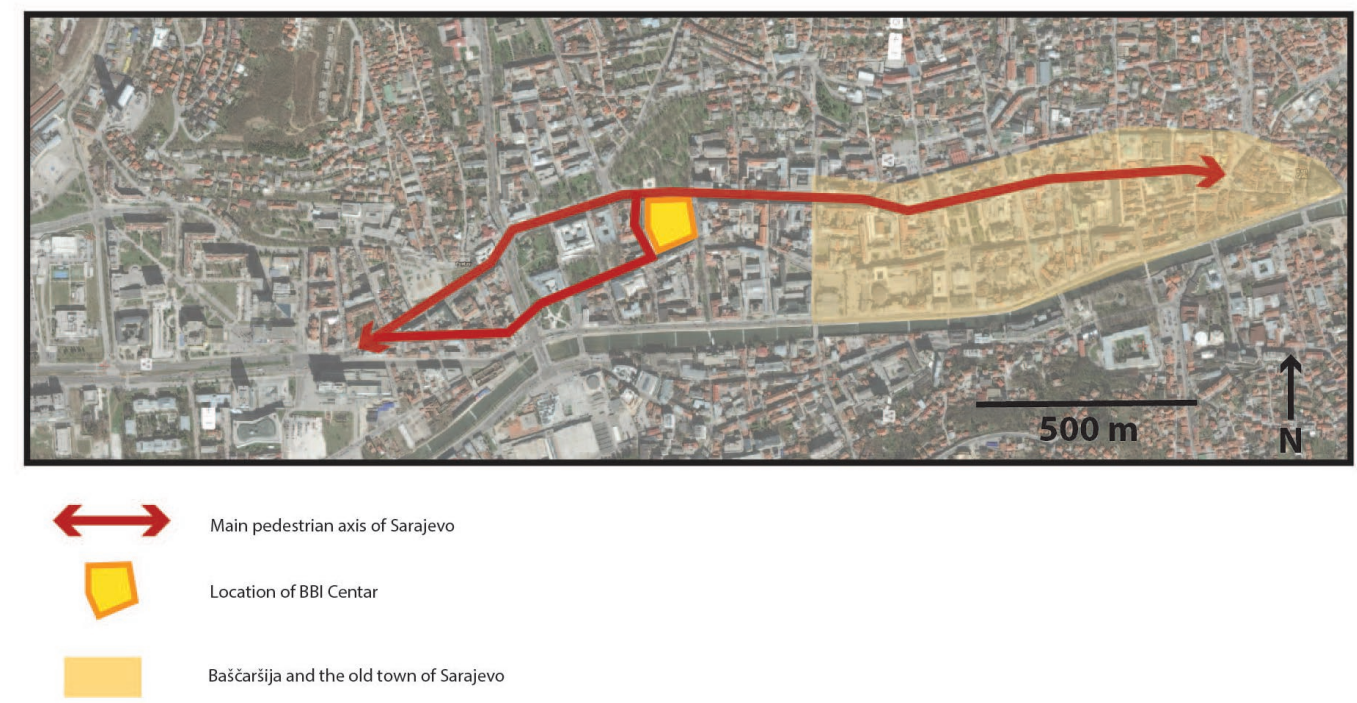

Figure 1: Localisation of BBI Centar in Sarajevo.

\footnotetext{
${ }^{2}$ Some neighbourhoods of Sarajevo were cut from the rest of the city and occupied by the Serb-Bosnian forces throughout the siege. Some of these neighbourhoods were re-integrated into the city (Grbavica, Ilidža), whereas some of them (Lukavica, Pale) formed the municipality of East Sarajevo populated by a majority of Serbs.
} 


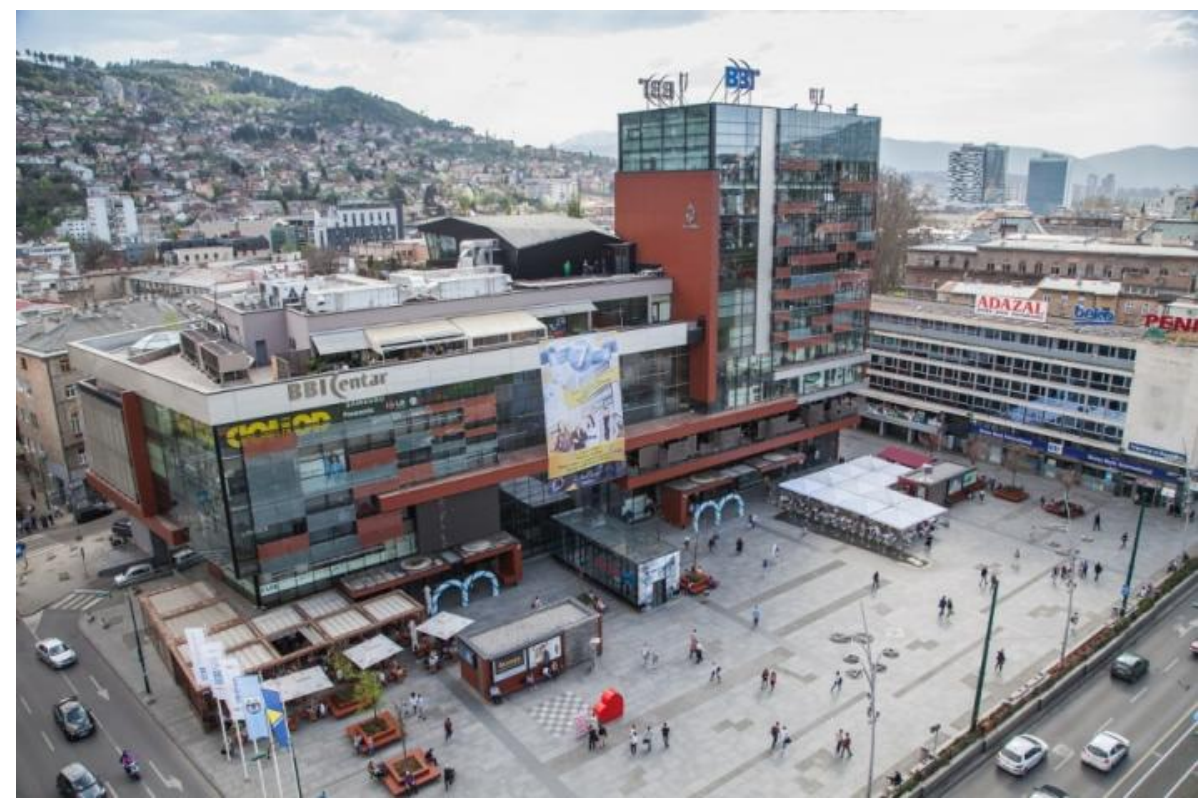

Figure 2: BBI Centar in 2016. BBI Centar 7th birthday. (n.d.). Source: Retrieved 7 July 2021, from https://www.bbicentar.ba/img/galerije/2016/04/img_4924_3.jpg

Since I started my research just before the Covid-19 pandemic, I was faced with an issue in terms of methodology, fieldwork became impossible and I couldn't collect field data. Fortunately, I managed to overcome this obstacle with digital tools such as Google Earth and Google Maps, blogs, forums, online press articles and online research. The pitfall of this method is that data are extensive, unverified or difficult to verify. Hence, I have focused on using them for archive images, information about the history of Sarajevo shopping centres, or to determine users' representations and discourses. Again, it should be reminded that these forums only bring together a tiny part of the population wishing to express themselves on an issue.

Online maps, found on archive sites, online shops of old maps or Google Earth and Google Maps allowed me to observe the spatial evolution of places. Google Earth also has a "little time machine" in its functionality. It is possible to see old satellite views and go back to March 2002 in Sarajevo, before the destruction of Sarajka and the construction of BBI Centar. The main interest of this method is the ability to easily observe the place's evolution over almost 20 years from 2002, just a few years after the war, to the present day. Including an analysis of how the environment changed and the location of the main amenities in the neighbourhood (parking lots, parks, and size of public spaces). However, this tool cannot provide a sense of the social atmosphere of these places. A shortcoming that can be overcome by looking into local media to retrieve information about the use of the space and past-events that took place there.

I used articles from Sarajevo's major media sources: the prominent local newspapers Dnevni Avaz, Oslovodenje, Vesti and Sarajevo Times, the web portals eKapija and Klix.ba, the radio and TV stations Al Jazeera Balkans, Radio Slobodna Evropa and Radio Sarajevo. The use of press articles has allowed me to gather information about the representations of consumption places in Sarajevo, the debates surrounding them or the events taking place there. I have also consulted academic work, such as Masters or PhD. theses, on places of consumption in Sarajevo, such as the ones of Moses Zev, Kristen Hartmann and Jordi Martín-Díaz (Zev, 2012; Martín-Díaz, 2017; Hartmann, 2018).

Taken from the French geography of trade (Desse, Lestrade, 2016), the notion of "mutation" underpins my attempt to trace minor evolutions in this shopping centre and distance myself from "transitology", a macro-sociological conception that studies the process of change from one political regime to another, I oppose to a bottom-up perspective. Observing these 
mutations in specific moments of history allows me to focus on direct actions carried out by actors in this particular place. This will enable me to avoid categories of analysis that rigidify social and historical contexts and play on the continuities and ruptures between different economic and social systems.

Among other things, I will discuss the notion of post-socialism through consumption, in particular through the role of private actors in the socialist and post-socialist cities. I will also examine how a shopping centre structured the socialist and post-socialist cities. Regarding private actors, I will further explore the relations of private investors with public authorities in the process of privatisation. I will also consider how the role of private actors has changed since the socialist era. I will analyse how the arrival of new foreign investors in a context of reconstruction and a lack of local funds have changed the making of the city and the local shopping centre. Regarding public spaces, I intend to look into the way private actors take part in the transformation of public spaces in socialist and post-socialist cities and trace continuities and discontinuities in the process of building spaces in Sarajevo. Finally, I will identify different narratives of globalisation that can be drawn from the study of places of consumption, such as the mall of BBI Centar.

\section{Trg oktobra, an informal centrality and place of consumption}

On BBI Centar current location, along the main street of Sarajevo, a new square, October Square (Trg oktobra in Bosnian), was built after the Second World War, with the destruction of several dwelling houses. There, Sarajevo's inhabitants met and gathered, bars, such as the popular kafana ${ }^{3}$ Istra, were set up, drinks and meals were sold, and the Dubrovnik cinema opened next door (Historijski Arhiv Sarajevo, n.d.).

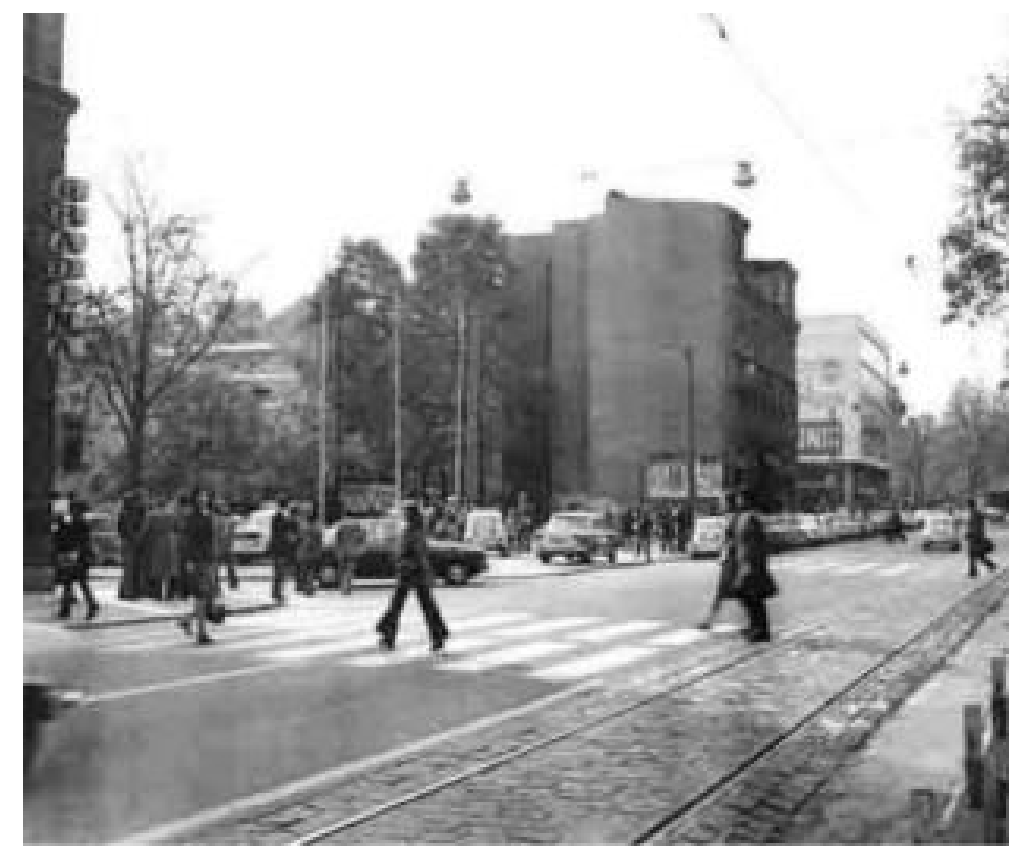

Figure 3: Trg Oktobra at the beginning of the 1960s. Source: Tulic, N. (2020, December 3). Post Twitter Nermin Tulic. Twitter. https://twitter.com/NerminTulic/status/1334441015244107776/photo/1

This small square as a new centrality of Sarajevo in the 1950s attracted the attention of planners and policymakers. Following a political order, Juraj Neidhardt ${ }^{4}$, a prominent Yugoslav

\footnotetext{
${ }^{3}$ Kafana: Local tavern which serves alcoholic beverages, coffee and snacks.

${ }^{4}$ Juraj Neidhardt (1901-1979). Student at the Academy of Fine Arts of Vienna, he is one of the most famous Yugoslav modern architects. His most significant work is the Ski Lodge on Mount Trebević close to Sarajevo, the
} 
modernist architect, designed a new development project for Sarajevo in the 1950s. In this project, four city squares located across the city, including Trg oktobra were to become the vectors of a new socialist lifestyle combining the opening of public spaces and a modernisation of social and cultural habits. In particular, Neidhardt imagined the development of a department store on Trg oktobra. In his project, the building would be low-rise and be placed close to a wide esplanade open to the city's inhabitants in order to provide large and accessible public spaces (54: Zatrić, Zatrić, 2014). Despite extensive planning, the project never materialised.

Afterwards, given the city's rapid development (Bojić, 2018), the municipal authorities wished to implement an urban project inspired by Neidhart's work on Trg oktobra (Harrington et al., 2019). Thus, in 1961, a pan-Yugoslav competition was launched, and an architect from Zagreb, Ante Glunčić ${ }^{5}$, was appointed to lead it. His project differed from Neidhart's as he proposed a plan to build a large edifice in the centre of the square, with the objective of increasing the area dedicated to commercial facilities by reducing the place of public spaces (Zatrić, Zatrić, 2014). For this reason, the project was criticised three years later by a group of architects formed around a certain Dimitrijević. According to these architects, commercial spaces took too much space and the population's needs for public spaces were not taken into account (54: Zatrić, Zatrić, 2014). Therefore, the group unsuccessfully proposed to build a structure on Trg oktobra dedicated to public and cultural uses such as a library or a cultural centre and to design a large square on the rest of the plot.

Planners and architects who wished to reorganise the spatiality of Sarajevo wanted to work on Trg oktobra by giving it precise and organised functions in accordance with the principles of Yugoslav modernism and socialism. It is also a place through which the modernisation of the city of Sarajevo should have taken place: a place open to the people thanks to public spaces and new ways of consuming thanks to the present consumption places. However, through the study of this place, even before the construction of the first mall, we can observe a part of the debates around consumption within Yugoslav society.

During this first period of existence of this place, as an informal leisure and commercial facility, mutations can be observed. We can notice that the emergence of a commercial and leisureoriented centrality in Sarajevo attracted the interest of planners and political authorities willing to manage and organise social evolution. As this area was gathering attention, it also became a place of discontent for other social groups and debates around consumption and public spaces as early as the 1960 s.

\section{Sarajka, a place for the new socialist society of consumption}

In the early 1970s, the public company Unima (Ujedinjena Investiciona Magacin) proposed the construction of a department store (robna kuća in Bosnian) on the site of Trg oktobra. The department store, inaugurated on 6 April 1974, was presented by its promoters as a gift to the city of Sarajevo to honour the $30^{\text {th }}$ anniversary of its liberation by the Yugoslav partisans. This project was a joint investment of three public companies: Unima, UPI and Stambeno Preduzeće Sarajevo. The department store, which was quickly nicknamed Sarajka by the locals, offered $11,000 \mathrm{~m}^{2}$ of retail space on five floors and contained 16 departments, a Unima Group supermarket, a snack bar, a restaurant, a credit service and storage areas, and employed around 500 people (Historijski Arhiv Sarajevo, n.d.). According to the shop's first manager, Nezir Mazur, Sarajka was the first shop in the city to offer such a wide range of products to the residents. The compound provided everything the people of Sarajevo needed; it was the biggest

Faculty of Philosophy of Sarajevo and the Parliament building of Bosnia and Herzegovina. Source: Juraj Neidhardt. (n.d.). Retrieved 27 October 2021, from http://architectuul.com/architect/juraj-neidhardt

5 Ante Glunčić (1931-1985). Student at the Faculty of Architecture of Zagreb he mainly worked in Croatia, especially in Zagreb. Source: Glunčić Ante. (n.d.). ULUPUH. Retrieved 27 October 2021, from https://ulupuh.hr/clanovi/gluncic-ante/ 
shop in Bosnia and Herzegovina at that time and the first place in the city where people could have a glimpse of consumption society and a new variety of goods and services (Historijski Arhiv Sarajevo, n.d.). Indeed, all the infrastructures that could support the development of consumer society in Sarajevo were present there, from consumer credit to shopping and restaurants. It was also a place that made the inhabitants proud by the modernity of the building (a spaceship that fell from space) and by the variety of products that could be found there (Bignotti, 2016). Sarajka was thus quickly seen as an important place for the city of Sarajevo and its inhabitants. The department store had a local and a national clientele, with visitors coming from all over Yugoslavia. Therefore, this project was seen as a way to raise Sarajevo to the level of other capitals of Yugoslav republics, such as Zagreb and Ljubljana, for the local authorities.

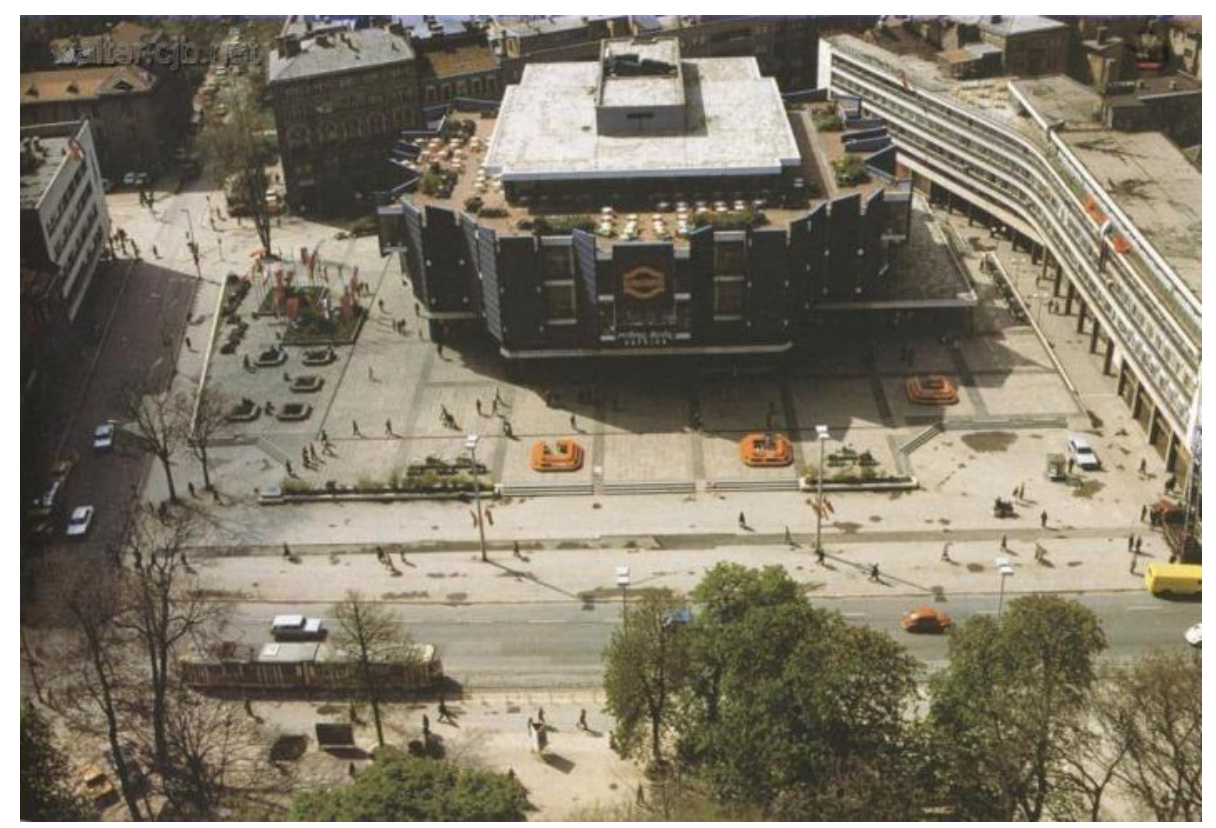

Figure 4: The department store Sarajka and its square during the 1980s.Source: Sarajevska Furka. (2019).

Sarajka.

https://www.facebook.com/SarajevskaFurka/photos/a.183590295333948/932173960475574/?type=3\&thea ter

Sarajka was one of a series of department stores built by various local companies at the same time in Yugoslavia. Indeed, there was a political plan to build 60 large shopping facilities of this type across Yugoslavia in the 1970s. This plan originated from the presentation of a prototype supermarket at the Zagreb Fair of 1968 by the United States delegation (Matijević Barčot, Grgić, 2015). These shops gathered many activities and were regarded as places of great importance for society and, therefore, public spaces.

Indeed, as in other countries with a socialist planning economy, from the 1960s, with the liberalisation of the regime, an opening towards the West, a decentralisation of party control and the promotion of hedonistic values by the League of Communists of Yugoslavia (SKJ), economic changes took place (Duda, 2005; Luthar, Pušnik, 2010). Increasingly important economic exchanges were symptomatic of the country's opening up to the world gaining access to Western credit in foreign currency fostered by connections with Western banks (Luthar, Pušnik, 2010; Ramet, 2006). This new economic situation led to the emergence of a middle class from the new elites of socialist society (skilled professions and workers, entrepreneurs) (Grandits, Taylor, 2010). The development of the middle classes and consumerism are thus strongly linked. As Breda Luthar and Maruša Pušnik argue, consumerism is not only the result of the emergence of a middle class but its' embodiment (Luthar, Pušnik, 2010). In the socialist 
Yugoslavia of the 1960s to 1980 s, there was thus a constitution of the self, construction of identity through consumer practices. This marks an individualisation of society and empowerment of individuals vis-à-vis their family and the dominant culture through consumption.

As in other European socialist societies, in Yugoslavia, economic development and consumer culture were primarily manifested in the increased availability of free time for the population (79: Duda 2005; Duda, 2016; 54: Dobrivojević, et al., 2014). Therefore, the Yugoslav state had to actively participate in the organisation of consumption and leisure for its inhabitants. As the architect, Sara Beslić recalls, "Tito valued sport, recreation and culture, and saw them as means to influence more widely the nation and also to promote 'culture for all' (82: Beslić, 2019). These complexes hosting several kinds of activities from sport to leisure and trade were designated for the organisation of gatherings to promote national unity and control the social and cultural life of the population. Thus, the authorities designed new spaces to organise the artistic and recreational needs of the inhabitants. In this way, leisure, sports and culture were also used to influence the population and were considered political mediators by the authorities (Štraus, 1998; Zagora, Samić, 2014). The architecture of these spaces also expressed the values of universalism and internationalism promoted by the Yugoslav model. This desire to mark space with an ideology can be seen in the 1960s in socialist Yugoslavia with the construction of sport and cultural centres and in the 1970s in the construction of department stores such as Sarajka.

These centres concentrating numerous activities were intended to create a place for society. An urban role was also given to these shopping centres, that of being an "urban patch" or structuring place for the new pedestrian streets built in the centre of Sarajevo and other Yugoslav cities similar to what the architects Sandra Matijević Barčot and Ana Grgić showed with the cases of Rijeka and Split in Croatia (Matijević Barčot, Grgić, 2015). For these department stores, older projects, such as Neidhart's and Glunčić's ones in Sarajevo, were taken over but modified by replacing cultural services with commercial ones, marking a transformation of Yugoslav socialism and its impact on the landscape of cities. These Yugoslav department stores were comparable with western ones built elsewhere at the end of the $19^{\text {th }}$ Century. Indeed, as department stores were places to sell standardised items (156: Lipovetsky, Serroy, 2013), Sarajka had the same function in a developing consumer society. With the show organised at its inauguration, it relied on the staging of consumption and promotion of the place with performances and celebrations, such as Macy's parade in New York City.

Like former projects previously mentioned, Sarajka was nevertheless criticised at the time of its construction for not conforming to socialist values. A group of architects, Aktiv Arhitekata, undertook an alternative study and proposed a new project (56: Zatrić, Zatrić, 2014). We notify here the tension between the implementation of new commercial projects and the proponents, often architects, of a city respecting the principles of socialism and having many public spaces. During this second phase, three other mutations can be observed as part of the development of the consumption society in Yugoslavia during the 1960s. This society of consumption was organised and promoted by the public authorities which presented it as truly socialist in its way of conforming to the needs of the people. With the development of new places of consumption, such as Sarajka, consumer urbanism became a tool used by municipal authorities to revitalise city centres. We should also add that another change allowed the development of this society, the internationalisation of consumption practices with the arrival of malls and supermarkets in Yugoslavia after 1960.

\section{Social transformations and the arrival of new international actors after 1990}

While the Warsaw block was in its final months and Yugoslavia's economic situation was deteriorating since the beginning of the decade, the 1989 Law on Social Capital, implemented 
by the government of Ante Marković, constituted a significant step in Yugoslavia's transition from a socialist to a capitalist system. At the same time, as several other countries witnessed similar financial difficulties, Yugoslavia underwent an austerity plan initiated by the IMF. These two elements accelerated the development, initiated since the mid-1970s, of privatnici (small trade entrepreneurship in Bosnian) and informal housing (Martín-Díaz, 2014). Concomitantly, a process of national affirmation occurred among Yugoslav Muslims ${ }^{6}$ and other ethnic groups of Yugoslavia (Bougarel, 2015). In Bosnia and Herzegovina, this trend was facilitated by the liberalisation of the regime and the increasing living standards among the population. At the same time, contrary to the case in the other republics of Yugoslavia (Bougarel, 2015), the Bosnian section of the communist party of Yugoslavia continued to adhere to its Titoist rigorism and was a victim of financial scandals such as the Agrokomerc one, an agricultural stated-owned company (Bougarel, 2015).

In this context, in February 1990, the Bosnian Parliament allowed the creation of parties but prohibited those based on national or religious affiliation. However, the constitutional court abolished this ban a few months later, and three major nationalist parties emerged: the Muslim $\mathrm{SDA}^{7}$, led by Alija Izetbegović, the Serb $\mathrm{SDS}^{8}$ and the Croat $\mathrm{HDZ} \mathrm{BiH}^{9}$. There were also two multi-ethnic citizen movements (Građanske stranke in Bosnian): the $\mathrm{SDP}^{10}$ and the SRSJ $^{11}$ supporting the federal Prime Minister Ante Marković (Bougarel, 2015). After an electoral campaign when nationalistic discourses were prevalent in Bosnia and Herzegovina, the power was shared between the three ethnic parties, the HDZ, the SDS and the SDA. The SDA leadership extensively relied on the internationalisation of the crisis to reverse the unfavourable domestic balance of power. From the end of 1990, the SDA took over international representation positions, and Izetbegović visited several Muslim countries such as Turkey, Iran, Libya, Saudi Arabia and Sudan between 1991 and 1992. When the war started in Croatia in March 1991, the party leadership tried to remobilise the networks it inherited from the Yugoslav non-alignment policy to gain political, financial and military support from Muslim states (Bougarel, 2015). There was also an interest in gaining support from the United States, which Izetbegović visited in 1991 and where many SDA executives formerly lived. However, internationalisation strategies soon reached their limits, and the conflict broke out in April 1992 without any international assistance secured.

During the war, Sarajevo suffered a lengthy siege from April 1992 to February 1996 held by the Bosnian Serb forces led by the SDS (Ristic, 2018). During this period, much of the city's infrastructure, means of transportation, sewage and electricity networks, and industries were destroyed by intense bombings (Husukić, Zejnilović, 2017; Zielińska, 2019; Martín-Díaz, 2021). Referring to this situation, the architect and former mayor of Belgrade, Goran Bogdanović, used the term urbicide ${ }^{12}$ to describe what the city of Sarajevo underwent during the war (Bogdanović, 1993). Since then, the infrastructure and housing have all been restored, although, the cultural and sports institutions have not regained their Yugoslavian glory.

The war also caused significant demographic changes, particularly with the arrival of refugees from Eastern Bosnia or Sandžak, in Serbia and Serbs fleeing from the city. Today 87\%

\footnotetext{
${ }^{6}$ Now referred to as Bosniaks.

${ }^{7}$ SDA: Stranka demokratske akcije (Movement of Democratic Action) was founded in May 1990.

${ }^{8}$ SDS: Srpska Demokratska Stranka (Serb Democratic Party) was founded in July 1990.

${ }^{9}$ HDZ: Hrvatska demokratska zajednica (Croatian Democratic Union of Bosnia and Herzegovina) was founded in August 1990.

${ }^{10}$ SDP: Socijaldemokratska partija (Social-Democrat Party) was founded in December 1992 as the descendant of the SKBiH, the Bosnian communist branch of Yugoslav communist party.

11 SRSJ: Savez reformskih snaga Jugoslavije (Union of Reform Forces of Yugoslavia) a pan-Yugoslav centreleft party was founded in July 1990.

${ }^{12}$ Urbicide refers to the willingness to destroy the essence of a city, its urbanity.
} 
of the population is Bosniak compared with 50\% in 1990. (38: Bădescu, 2015). At the same time, the population of the city dropped significantly from over 500,000 to around 400,000 and a large part of the Serbs fled the city during the year or just after the end of the conflict during 1996 (Martín-Díaz, 2021).

After several attempts and rounds of discussion, the Dayton Agreement signed on 14 December 1995 provided a way out of the conflict. As a result, Bosnia and Herzegovina retained its international borders but was highly decentralised and divided into three entities, the Croat and Bosniak Federation of Bosnia and Herzegovina, the Serb Republika Srpska and the district of Brčko. The Federation of Bosnia and Herzegovina, where Sarajevo is located, is itself subdivided into ten autonomous cantons with their own governments. Because of this political organisation, in Bosnia and Herzegovina, the process of privatisation has its particularities when compared with other central and eastern European countries. The process is highly decentralised since each canton has its own privatisation agency such as the KAPSA ${ }^{13}$ in Sarajevo, while there is usually only one agency per country elsewhere. This combined with the emergence of a corrupted ethnocracy, caused difficulties in monitoring privatisation and detecting corruption (Pobric, Robinson, 2019; Martin-Diaz, 2021).

With the war and the dissolution of Yugoslavia in the 1990s, we can observe the three following mutations. At first, the Bosnian society witnessed a process of ethnicization with the formation of ethnic political parties, their access to power and a demographic change in the population of Sarajevo. Secondly, there was a phenomenon of economic, cultural, and political globalisation in Sarajevo with the arrival of new models of modernity. Furthermore, finally, with the signature of the Dayton Agreement, there was a decentralisation of political decisionmaking.

\section{The privatisation of Unima and the emergence of new international actors}

Completely destroyed by bombings during the siege of the city, the department store of Sarajka was sold by the privatisation agency KAPSA to the Islamic bank BBI Banka ${ }^{14}$, which had the project to build a new shopping centre, in 2002, for 9 million euros (Zatrić, Zatrić, 2014) or 6 million euros (Martin-Diaz, 2021) according to the sources.

This privatisation was completed thanks to a tender promoted by the Framework Law on Privatisation enforced by the OHR ${ }^{15}$ Carlos Westendorp in July 1998, which encouraged the use of tenders (Martín-Díaz, 2021). Before that, the Italian company Benetton came up with a proposal to buy this land for 38 million euros before the announcement of the tender but it stepped back in March 2001 after this tender was published. It stepped back again later on, this time because of the economic instability of Bosnia and Herzegovina and the cost of the plot considered too high by the Italian company (99: Martin-Diaz, 2021; 122: Hartmann, 2018). In 2002, when KAPSA launched the third tender, three candidates answered: Benetton made another offer of 6 million euros, BBI Banka proposed the same amount and Inter Invest, a local investment group, offered the highest amount with 6.25 million euros (99: Martín-Díaz, 2021). Although Inter-Invest was in a position to win the tender, the owner of the group, Dinko Slezak, withdrew without any explanation, and Benetton won the bid in April 2002. However,

\footnotetext{
${ }^{13}$ KAPSA : Kantonalna agencija za privatizaciju Sarajevo (Sarajavo Cantonal Agency for Privatisation).

${ }^{14}$ BBI Banka was founded in October 2000 with a capital of 47 million Bosnian marks by three Islamic investment banks (all of them are based in the Gulf). As stated on the website of BBI Banka: $45.46 \%$ of funds come from the Islamic Development Bank, and the other 54,54\% are equally shared between the Dubai Islamic Bank (the first Islamic bank) and the Abu Dhabi Islamic Bank. BBI Banka is the first European Islamic bank.

15 Office of the High Representative, the highest political function in Bosnia and Herzegovina created after the signing of the Dayton Agreement in December 1995. The OHR has vast powers including the power of veto and is appointed by the international community.
} 
Benetton's managers did not show up for the contract signature on 10 June 2002 in the KAPSA offices, and BBI Banka won the contract (100: Martín-Díaz, 2021). According to the geographer Jordi Martin-Diaz who researched the transformation of post-war Sarajevo, pressures were allegedly put on Benetton to make way for BBI Banka (100: Martín-Díaz, 2021). The reasons explaining the investment of BBI Banka in the sector of shopping facilities are controversial, and very little information can be found about this. Previous research postulated that in the early 2000s, BBI Banka was a bank that made little profit; it even had losses of nearly 2 million euros in 2004. To get out of this situation, the bank turned to real estate investment, which seemed more lucrative (Zev, 2012). However, this assertion remains poorly documented and needs to be verified.

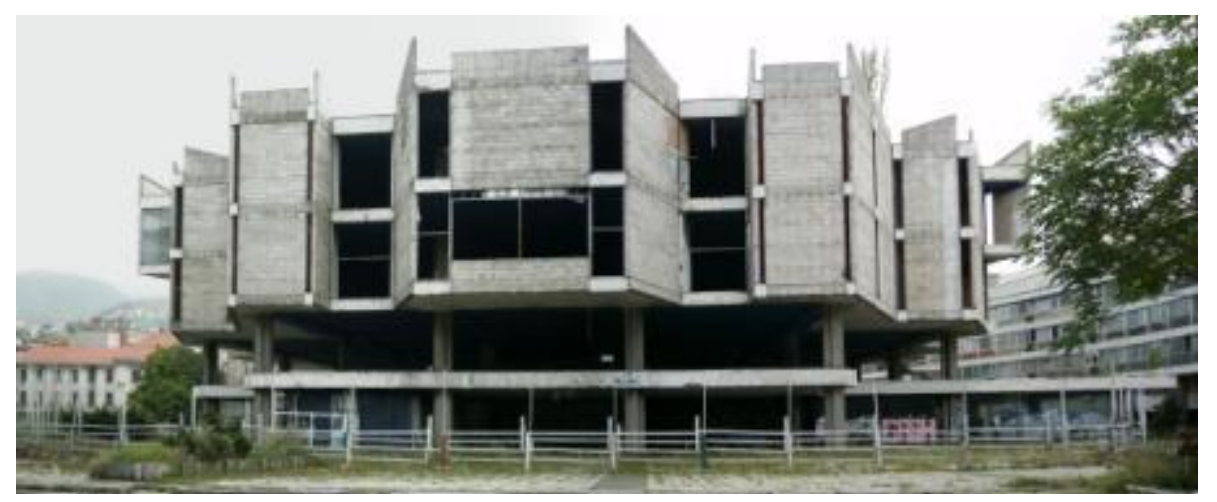

Figure 5: Sarajka after its destruction in 2005. Source: BiHvolim. (2005). Robna kuća Sarajka (today BBI Centar). https://commons.wikimedia.org/wiki/File:Robna_ku\%C4\%87a_Sarajka_(today_BBI_Centar).jpg

Another hypothesis is linked to BBI Banka's status as an Islamic bank. Islamic banks are financial institutions that adhere to sharia (Islamic norms and rules) regarding their financial activities. In Islamic finance, a bank must back its financial operations with a tangible asset, such as cattle, gold or land (Jouaber-Snoussi, 2012). Money is thus considered in Islamic finance solely as a medium of exchange, since trading in money is forbidden, and there can be no profit on financial transactions only. As it is proven by des Vallières in the case of Tehran, in Iran, where the construction of shopping centres skyrocketed, even if these complexes have a low rate of profitability, they remain an asset of quality in Islamic finance, as their value increases or at least remains stable (des Vallières, 2018). In this sense, the formation of real estate capital for the bank BBI was a way to have a real estate asset, therefore tangible, and secure its operations. BBI Real Estate was therefore created as a subsidiary of BBI Banka to develop the shopping centre (BBI Centar, n.d.).

Like previous transformations of the site, the purchase of the landholdings of Unima by BBI Banka sparked various reactions in Sarajevo. Press reports and numerous rumours and discourses were presented as understandable explanations to a situation, pointing to suspicions of corruption surrounding privatisation. Indeed, strong connections are documented between the SDA and BBI Banka. In order to add credit to these assertions, earlier research points out that the creation of BBI Banka by three Islamic banks based in the Gulf countries is said to come from connections established by the SDA's lobbying campaigns in Islamic countries during the 1990s (45: Zev, 2012). It is also proven that there exist strong personal connections between members of the historical SDA, people who founded the party in 1990 and were companions of its founder Alija Izetbegović as early as in the 1980s and personalities from the economic worlds in the Gulf (Bougarel, 2015). These connections come from the search for economic support and weapons during the war and the search for investments after it (Bougarel, 2015). These connections are visible through the place of foreign actors in Post-Dayton BosniaHerzegovina in projects concluded by local governments with international financial actors and 
Islamic states, especially around heritage restoration for Turkey or religious and education matters for Malaysia or Saudi Arabia (Pobric, Robinson, 2019). Suspicions of corruption are also supported in the press by the fact that the founding of BBI Banka had economically strengthened executives of SDA by offering them managerial positions and a foothold in the post-war reconstruction economy (Zev, 2012; Martín-Díaz, 2021).

Thus, Hasan Čengić, Haris Silajdžić and Bakir Izetbegović (the son of Alija Izetbegović) influential SDA individuals, were all members of the Board of Directors (Upravni Odbor in Bosnian) of BBI Banka and referred to as "founding honourable patron" by the bank (Zev, 2012). According to other sources, Bakir Izetbegović is said to have earned nearly 15,000 euros from this position and been paid 2,500 euros per month by BBI Banka to monitor the construction of the new shopping centre (124: Hartmann, 2018). The same Bakir Izetbegović was also the director of the Institute of Construction of Sarajevo (Zavod za izgradnju Kantona Sarajevo in Bosnian) between 1991 and 2003 and then a key person in the construction business (107: Martín-Díaz, 2021).

The press also criticises the opacity of privatisation processes of the KAPSA. BBI Banka is thus said to have become an important centre of power in Bosnia and Herzegovina, in particular by concentrating the interests of large Bosnian families, the Čengić, Živalj, Izetbegović and Bukvić, and by offering members of the SDA access to important decisionmaking positions (64: Zev, 2012; 100: Martín-Díaz, 2021). Corruption and the links between political and economic elites are highlighted. It is a place where the problems of post-war Bosnian society can be observed and discussed. BBI Banka has also enabled the SDA leadership to put forward a new development model based on Islamic finance and its associated norms (use of tangible assets in finance, respect of sharia in economic activities and development of a halal industry in tourism and trade). Although BBI Banka strengthens economic relations between the Islamic world and Bosnia, the funds attracted remain limited and are restricted to real estate investments (45: Zev, 2012).

By analysing the privatisation of the public company Unima, owner of the department store Sarajka, we have seen extensive privatisation of public assets during the second part of the 1990s and the early 2000s in Sarajevo. This privatisation was the occasion for the emergence and installation of international actors in the commercial sector, such as BBI Banka. In this context of intense privatisation and development of investor urbanism, urban spaces tend to be financialised, and real estate truly became a financial asset for potential investors and banking actors, as Ludek Sýkora and Stefan Bouzarovski observed in the case of other post-socialist cities (Sýkora, Bouzarovski, 2012). These elements drive discourses on corruption and participate in the construction of Sarajevo's identity.

\section{The return of a commercial centrality in Sarajevo with BBI Centar}

After an investment of 35 million euros by BBI Banka (Hartmann, 2018), the new shopping centre, called BBI Centar after its investors, was inaugurated with grand style on the 6th of April 2009, exactly 35 years after the opening of the department store Sarajka (FENA, 2009). The arrival of this new shopping centre was an important event in the city as the construction of BBI Centar marked the implementation of the first shopping centre with international franchising, such as DM, Okaïdi, Timberland or Ralph Lauren, and leisure activities in Sarajevo. The inauguration of BBI Centar was the occasion for its promoters to publicise their role in the fabric of Sarajevo's urbanity. With the same spirit as Nezir Mazur, the first director of Sarajka, Andre Van Hove, the head of BBI Banka, indicated at the inauguration that he "wants to give to Sarajevo something beautiful", a recognisable object that allows the city to compete with others in the region (Zatrić, Zatrić, 2014). After its inauguration, BBI Centar became a place that represented Sarajevo and extended its influence in the metropolitan region of Sarajevo and other cities of Bosnia and Herzegovina. Therefore, this construction 
participated in the metropolization of Sarajevo that already started during socialism (Bojić, 2018) and to the concentration of activities in the city centre of Sarajevo, a phenomenon documented in other post-socialist cities (Sýkora, Bouzarovski, 2012).

Although BBI Centar is now considered a representative place of Sarajevo and a marker of its urban identity, its access is relatively closed for a large part of the population. Indeed, shops in the shopping centre are, for a majority of them, not accessible because of their high prices. The boutiques of BBI Centar are very expensive compared to what is available elsewhere in town: jackets, dresses and trousers cost about 300 marks $^{16}$, the equivalent of onethird of the median salary (Agencija za statistiku Bosne i Hercegovine, n.d.). Window shopping is then prevalent due to high prices and encouraged because the place was designed to encourage this type of behaviour. It is indeed possible to see the other customers and above all to be seen by them thanks to the presence of large windows in front of the shops and the main hall's open architecture.



Figure 6: The main hall of BBI Centar (author, July 2021)

\footnotetext{
${ }^{16}$ Approximately 150 euros.
} 


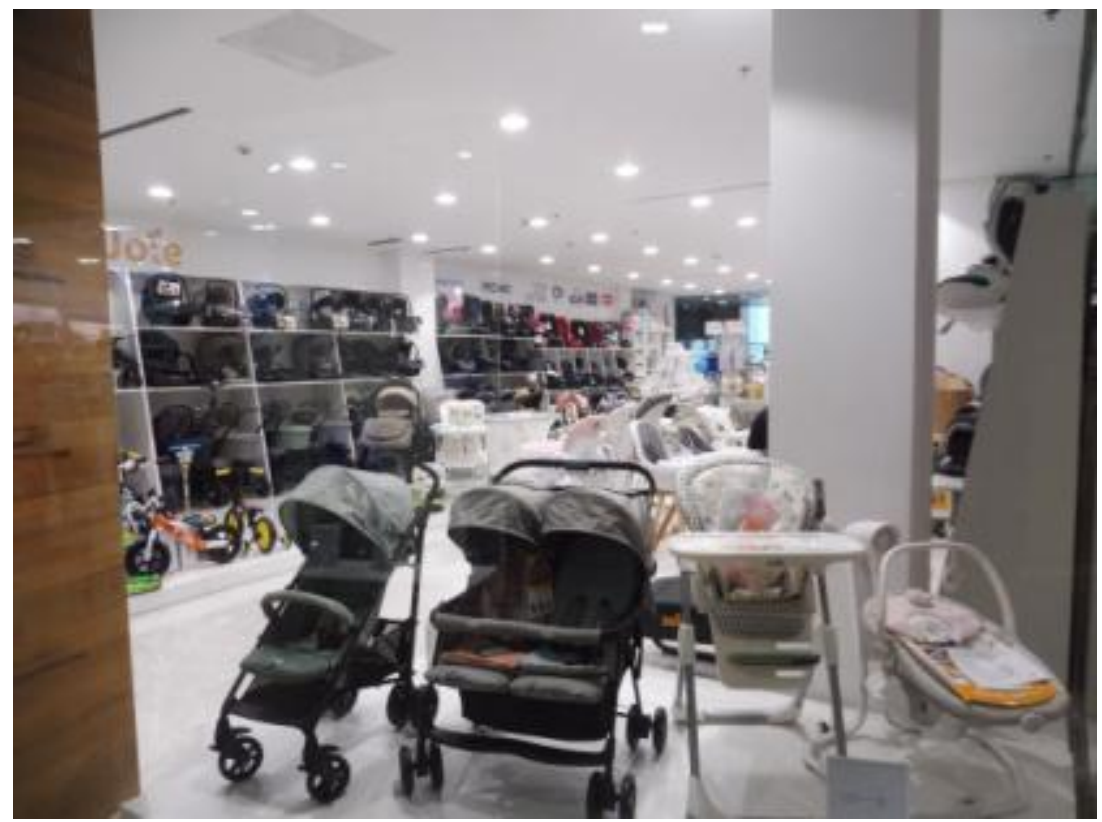

Figure 7 : A shop from the corridors of the shopping centre (author, July 2021)

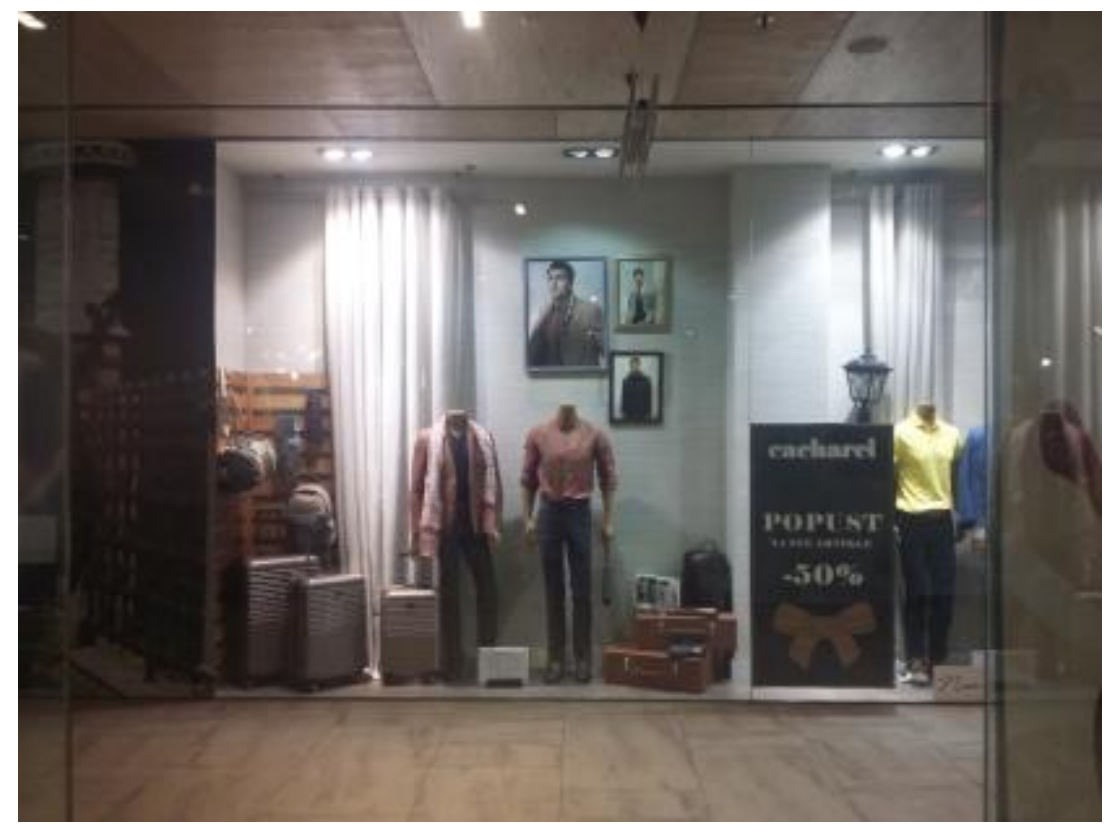

Figure 8: A shop from the corridors of the shopping centre (author, July 2021)

BBI Centar was imagined as a place where people could meet, in the square and around a coffee. However, as with the items proposed by the shops, prices are also very high compared to local standards. As observed, the price of coffee is between 2 and 2.5 marks in the two coffees houses of the shopping centre, Cordoba and Elements, whereas a cup usually costs between 1.5 and 2 marks elsewhere in town. Food is priced about 10 marks for one meal in the same places (from 10 marks for a pizza to 15 marks for a complete dish ${ }^{17}$ ), about the same price as in an upmarket restaurant in Baščaršija, the old town. Consequently, BBI Centar mainly attracts tourists or wealthy foreigners and participates in the gentrification of the city centre, mainly

\footnotetext{
${ }^{17}$ Approximately 5 and 7.5 euros.
} 
through tourism, because of the strong presence of Middle Eastern tourists (50,000 people from the region in 2017) (292: Pobric, Robinson, 2019). Their presence is important probably because the shopping centre attracts them by the nature of products proposed by the shops (souvenirs, perfume, and jewellery) and the respect of Sharia (neither alcohol nor pork is sold in the shopping centre). However, it has to be said that this place is not seen as Islamic by nature for many of its local users (Martín-Díaz, 2021).

With its large public square, Trg Djece Sarajeva (Square of Children of Sarajevo), free of access, located along the main street and facing a popular public park, despite being frequented by many tourists, BBI Centar remains an important place in the life of the city and its inhabitants. People meet there, rest on the benches for a few minutes during their evening walk, New Years' Eves are celebrated there with concerts and fireworks, and associations and NGOs regularly organise events in the square (Boračić-Mršo et al., 2010). For example, the Bosnian Red Cross organised an exhibition showing portraits of people having no news of family members who disappeared during the last war (PORTAL Oslobođenje, 2019). Moreover, more political demonstrations were organised there; for instance, the association Udruženje Front ('Civil Front' in Bosnian) organised a rally in support of civilians during the bombing of Gaza in November 2012 (Arnautović, 2012). These examples show that $\mathrm{BBI}$ Centar is a real political space where opinions and public matters are exhibited.

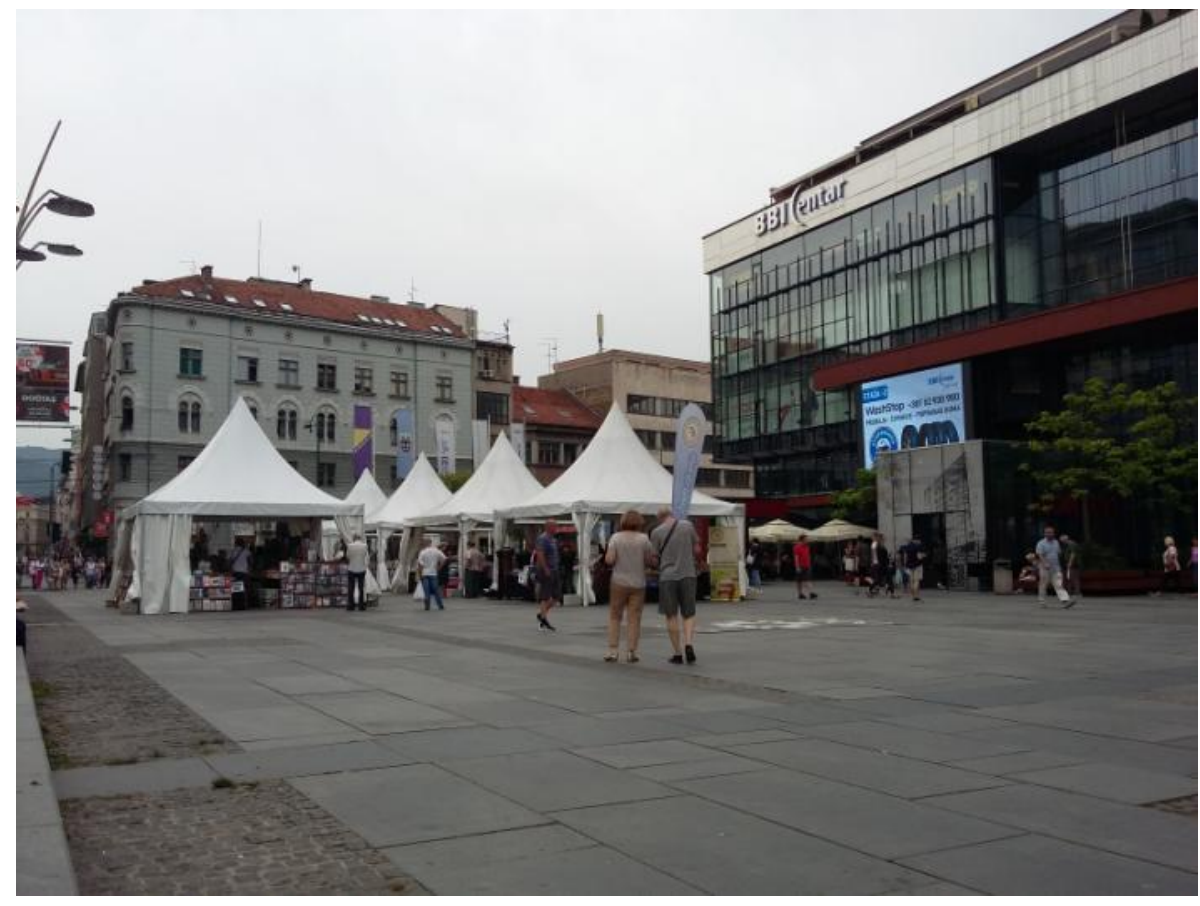

Figure 9: Trg Djece Sarajeva, the square in front of the shopping Centre (Author, July 2021).

However, because BBI Real Estate, a subsidiary of BBI Banka, is in charge of the development of the shopping centre and the square in front of it, organisations willing to organise an event in this square are required to ask permission from BBI Real Estate, the owner of this place. Hence, some events have not been authorised. As an example, Sarajevski Otvoreni Centar (Open Centre of Sarajevo), an association advocating for the rights of women and LGBT, wanted to organise an action for the day of visibility of transgender people in March 2018 (Sarajevski Otvoreni Centar, 2018). According to press articles, the association claims that BBI Real Estate did not allow the organisation to organise this event in the square because another one was planned for that day. However, a second reason was also given by BBI Real Estate. They claimed that because they could not guarantee the safety of the participants in 
"high-risk activities that require additional protection of the spaces as well as third persons", the event could not take place in front of BBI Centar. The association claims not to have received any further explanations, despite having sent emails, even though it is the responsibility of the cantonal authorities to carry out studies to assess the need for supervision during an event. In this case, Sarajevski Otvoreni Centar criticised the control of a private institution over a public space and the inability of the inhabitants to express themselves freely in it.

This story marks that some events and subjects are welcome in front of the place and that a private entity manages political expressions over the square. Events must be acceptable for the reputation of an Islamic bank such as BBI Banka, the holding company of BBI Real Estate: Such as a protest against bombings in Gaza, a campaign of information about public expenses and budgets (Avaz.ba, 2017) or public celebrations for national holidays; however, when an event can risk harming the reputation of the shopping centre and thus its investor, the bank, its tranquillity or apparent politicisation, it is not authorised by the bank which is the real authority of this city centre square.

In this last part of the history of this place, we can see the latest developments that Sarajevo has witnessed. We have the development of large retail centres and their importance in the urban landscapes and life of inhabitants. At the same time, we can notify a control and administration of public spaces by private companies, such as BBI Banka, because of their legal possession of such places.

\section{Conclusions}

This article addresses the evolution of business forms in different consumer societies, the difference between public and private management of consumption and the debates around the construction of commercial areas through different periods. Through this text, some of the commercial developments Sarajevo experienced in the last 70 years were displayed. Accordingly, their accumulation allows us to generate a dynamic evolution of this city under the prism of consumption.

At first, in the 1960s and 1970s, there was the emergence of new forms of consumption and developing connections between consumption and leisure, notably in the urban context and landscape. With these elements, we can discuss the nature of the economic and political situation that took place at that time and state the emergence of a market economy within the framework of a socialist state during the 1960s, 1970s with the arrival of para-public actors, such as Unima, and their importance in the evolution and dynamics of the city. This follows previous research such as that of Benczes (2016), retracing the slow evolution of Hungarian society from the 1960 s to current times. The period of reconstruction that followed the war highlighted the processes of privatisation and globalisation of financial exchanges in Sarajevo. They are simultaneous with the arrival of foreign economic actors, such as Islamic banks and the financialisation of urban spaces.

Finally, recent years consisted of a pause in the development of shopping facilities after 2015 after a significant increase in their size. This growth in the size of shopping centres is a sign of a change in their function. With expensive shops, hardly accessible to the local population, but open public spaces, they lost a part of their commercial function and are returning to places mainly devoted to leisure and public meetings, as they were thought during socialist Yugoslavia. Furthermore, the proliferation of real estate projects in the tourism sector indicates that shopping centres were, after all, a financial investment integrated into a land asset development strategy explained by the development of Islamic finance in Bosnia and Herzegovina. 


\section{References}

Agencija za statistiku Bosne i Hercegovine. (n.d.). Agencija za statistiku Bosne i Hercegovine. Retrieved 26 October 2021, from https://bhas.gov.ba/Home/

Aquilue, I., \& Estanislao, R. (2016). Urban development after the Bosnian War: The division of Sarajevo's territory and the construction of East Sarajevo. Cities, 58, 152-166.

Arnautović, M. (2012). Sarajevo: Skup podrške civilima u Gazi. Radio Slobodna Evropa. https://www.slobodnaevropa.org/a/sarajevo-skup-podrske-civilima-ugazi/24779720.html

Avaz.ba. (2017). Gomila novca ispred BBI centra: Pred građanima Sarajeva više od 40 miliona KM. $\quad$ https://avaz.ba/vijesti/bih/310155/gomila-novca-ispred-bbi-centra-predgradanima-sarajeva-vise-od-40-miliona-km

Bădescu, G. (2014). City Makers, Urban Reconstruction and Coming to terms with the Past in Sarajevo. In Reconstructing Sarajevo: Negotiating Socio-political Complexity (pp. 1422). LSE.

BBI Centar. (n.d.). About us $\mid$ BBI Centar Sarajevo. Bbicentar.Ba. Retrieved 26 October 2021, from http://www.bbicentar.ba/eng/about us.html

Beslić, S. (2019). The Scars of Sarajevo \& Skenderija's Place. Azrieli School of Architecture \& Urbanism Carleton University.

Bignotti, I. (2016). The Concrete Utopia - Ivan Picelj and New Tendencies - 1961-1973. Ilaria Bignotti.

Bogdanović, B. (1993). Grad kenotaf. Durieux.

Bojić, N. (2018). Social and Physical Planning: Two Approaches to Territorial Production in Socialist Yugoslavia between 1955 and 1963. Architectural Histories, 6(1), 25.

Boračić-Mršo, S., Borović, R., Glavonjić, Z., Šćepanović, L., Zebić, E., \& Zejneli Loxha, A. (2010). Para, posla i zdravlja. Radio Slobodna Evropa. https://www.slobodnaevropa.org/a/region_ocekivanja_nova_godina/2263611.html

Bougarel, X. (1996). Bosnie, anatomie d'un conflit. La Découverte.

Bougarel, X. (2015). Survivre aux empires. Islam, identité nationale et allégeances politiques en Bosnie-Herzégovine (Meydan). Karthala.

Bougarel, X., Helms, E., \& Duijzings, G. (Eds.). (2007). The New Bosnian Mosaic. Identities, Memories and Moral Claims in apost-war society.Ashgate.

Desse, R.-P., \& Lestrade, S. (2016). Mutations de l'espace marchand. Presses Universitaires de Rennes.

Des Vallières, R. (2018). Pourquoi tant de malls à Téhéran? Éléments d'économie politique des centres commerciaux en République islamique (1987-2017). EchoGéo, 45. https://doi.org/10.4000/echogeo.15333

Dobrivojević, I., Duda, I., \& Mihelj, S. (2014). They Never Had it Better? Modernization of Everyday life in Socialist Yugoslavia. Muzej Jugoslavije.

Duda, I. (2005). U potrazi za blagostanjem-O povijesti dokolice i potrošačkog društva u Hrvatskoj 1950-ih i 1960-ih. Srednja Europa.

Duda, I. (2016). When capitalism and socialism get along best: Tourism, consumer culture and the idea of progress in Malo misto. In Social inequalities and discontent in Yugoslavia. Routledge.

Em, P., \& Ward, P. (2021). City profile: Is Pyongyang a post-socialist city? Cities, 108.

FENA. (2009). Svečano otvoren BBI Centar u Sarajevu. Klix.ba. https://www.klix.ba/vijesti/bih/svecano-otvoren-bbi-centar-u-sarajevu/090406142

Geoffray, M.-L. (2013). La Havane après 1989: Vers une ville post-socialiste? In Ségrégation et fragmentation dans les métropoles (pp. 155-170). Presses Universitaires du Septentrion. 
Goldstein, P. (2015). Grassroots Narratives and Practices of Diversity in Mostar and Novi Sad. In Governing through Diversity Migration Societies in Post-Multiculturalist Times (p. 213). Palgrave Macmillan.

Grandits, H., \& Taylor, K. (2010). Yugoslavia's Sunny Side: A History of Tourism in Socialism $(1950 s-1980 s)$. Central European University Press.

Gül, M., \& Dee, J. (2015). Sarajevo-A city profile. Cities, 43, 152-166.

Gül, M., \& Omićević, N. (2013). Old Market v. Shopping Malls: The Impacts of Changing Consumer Practices on Sarajevo's Urban Morphology. AE Revista Lusofona de Arquitectura e Educacao-Architecture and Education Journal, 8-9, 673-693.

Hanson, P. (1974). Advertising \& socialism. A Study of the Nature and Extend of Consumer Advertising in the Soviet Union, Poland, Hungary and Yugoslavia.Palgrave Macmillan.

Harrington, S., Dimitrijevic, B., \& Ashraf, S. (2019). Synchrony-city: Sarajevo in five acts and few intervals. Synchrony-City: Sarajevo in Five Acts and Few Intervals, 13, 573-594.

Hartmann, K. (2018). Identity and Urban Investment in Sarajevo: Transnational Flows of Capital from the Persian Gulf and Post-conflict Imaginaries of Belonging. School of Slavonic and East European Studies University College London.

Haupt, H. (2012). Small Shops and Department Stores. In The Oxford Handbook of the History of Consumption (pp. 267-285). OUP Oxford.

Hirt, S. (2012). Iron curtains gates, suburbs and privatization of space in the post-socialist city. Wiley Blackwell.

Hirt, S., Tuvikene, T., \& Ferenčuhová, S. (2017). Conceptual forum: The "post-socialist" city. Eurasian Geography and Economics, 57(4), 1-24.

Historijski Arhiv Sarajevo. (n.d.). Sarajka-Historijski arhiv Sarajevo. Historijski Arhiv Sarajevo. Retrieved 17 February 2021, from http://www.arhivsa.ba/wordpress/?tag=trgoktobra

Husukić, E., \& Zejnilović, E. (2017). The environmental aesthetics of Sarajevo: A city shaped by memory. Urbani Izziv, 28(1), 96-106.

Jouaber-Snoussi, K. (2012). La finance islamique. La Découverte.

Karčić, H. (2010a). Globalisation and Islam in Bosnia: Foreign Influences and their Effects. Totalitarian Movements and Political Religions, 11(2), 151-166.

Karčić, H. (2010b). Islamic Revival in Post-Socialist Bosnia and Herzegovina: International Actors and Activities. Journal of Muslim Minority Affairs, 30(4), 519-534. https://www.tandfonline.com/doi/abs/10.1080/13602004.2010.533450

Le Normand, B. (2017). The Contested Place of the Detached Home in Yugoslavia's Socialist Cities. In The Cultural Life of Capitalism in Yugoslavia (Post)Socialism and Its Other (pp. 173-190). Palgrave Macmillan.

Luthar, B., \& Pušnik, M. (2010). Remembering Utopia, culture of everyday life in Yugoslavia. New Academia Publishing.

Lipovetsky, G., \& Serroy, J. (2013). L'esthétisation du monde. Gallimard.

Martín-Díaz, J. (2014). Urban restructuring in post-war contexts: The case of Sarajevo. Hungarian Geographical Bulletin, 63(3), 303-317.

Martín-Díaz, J. (2017). Geopolitical and urban changes in Sarajevo (1995-2015) [Universitat de Barcelona]. http://diposit.ub.edu/dspace/handle/2445/124651

Martín-Díaz, J. (2021). The Urban Transformation of Sarajevo: After the Siege, the Role and Impact of the International Community. Springer.

Matijević Barčot, S., \& Grgić, A. (2015). Shopping as a Part of Political Agenda: Emergence and Development of Shopping Centre Typology in Socialist Croatia (1960-1980). In 
The Shopping Centre 1943 -2013: The Rise and Demise of a Ubiquitous Collective Architecture (pp. 85-97).

Müller, M. (2019). Goodbye Postsocialism! Europe-Asia Studies, 71(4), 533-550.

Nurković, R. (2016). The city of Sarajevo as the focal point of the development of spatial planning. Mjesto i uloga glavnih gradova see (jugoistočne Evrope) u razvoju međuregionalne i međudržavne suradnje u okviru dunavske i jadransko-jonske evropske makroregije.

Pobric, A., \& Robinson, G. M. (2019). Recent urban development and gentrification in postDayton Sarajevo, Bosnia and Herzegovina. Cities, 89, 281-295.

PORTAL Oslobođenje. (2019). Obilježavanje Dana nestalih osoba u Sarajevu. https://www.oslobodjenje.ba/vijesti/sarajevo/foto-obiljezavanje-dana-nestalih-osobau-sarajevu-486232

Ramet, S. (2006). The Three Yugoslavias: State-Building And Legitimation, 1918-2005. Indiana University Press.

Ristic, M. (2018). Architecture, Urban Space and War. The Destruction and Reconstruction of Sarajevo. Palgrave Macmillan.

Sarajevski Otvoreni Centar. (2018, March 28). MEDIA ANNOUNCEMENT: Who and how is deciding on freedom of assembly of citizens of Sarajevo? Sarajevski Otvoreni Centar. https://soc.ba/en/media-announcement-who-and-how-is-deciding-on-freedom-ofassembly-of-citizens-of-sarajevo/

Štraus, I. (1998). Arhitektura Bosne i Hercegovine 1945.-1995. =: The architecture of Bosnia and Herzegovina 1945-1995.

Sýkora, L., \& Bouzarovski, S. (2012). Multiple Transformations: Conceptualising the Postcommunist Urban Transition. Urban Studies, 49(1), 43-60.

Vasilevska, L., Milanović, D., Nikolić, M., Vranić, P., \& Milojković, A. (2015). “Garage capitalism" as a form and process of post-socialist urban changes: Its pace, intensity and structural characteristics. A case study of Nis, Serbia. Habitat International, 48, 149158 .

Zagora, N., \& Samić, D. (2014). Sarajevo lost in transition? Ideologies and their representational spaces. International Journal of Architectural Research, 8(1), 159170.

Zatrić, M., \& Zatrić, Z. (2014). The (futile) architectural cultures of dissent: Or (post-)socialist urban-transformation-as-usual. In Reconstructing Sarajevo: Negotiating Socio-Political Complexity (pp. 52-60). LSE.

Zev, M. (2012). Neo-Liberalism, the Islamic Revival, and Urban Development in Post-War, Post-Socialist Sarajevo [Master of Arts in Geography Department of Geography and Program in Planning]. Université de Toronto.

Zielińska, J. (2019). Archaeology of desire Urban palimpsest-Unveiling invisible sites of Sarajevo. In Civic Spaces and Desire (p. 234). Routledge. 